\title{
„ALBAŃSKA GOLGOTA”- EXODUS SERBÓW NA KORFU W CZASIE I WOJNY ŚWIATOWEJ W DYSKURSIE PUBLICZNYM MIĘDZYWOJENNEJ JUGOSŁAWII
}

\author{
PAWE€ MichalAK
}

\begin{abstract}
Albanian Golgotha" - the exodus of Serbs to the Corfu island during World War I in the public discourse of interwar Yugoslavia

Both the Balkan Wars and World War I, and particularly the great migration of the Serbian army during the retreat to the Corfu island, which imprinted in the collective memory as the Albanian Golgotha, were among the most important reference points in the public discourse of interwar Yugoslavia. Official government circles tried to present them as the cornerstones for the building of a unified state of the Southern Slavs. The authorities supported all the initiatives which were commemorating those events. King Alexander Karađorđević was one of the most active in this field, he repeatedly personally graced the celebration of all events and battles or honoured their heroes. However, it should be noted that the Albanian Golgotha was such an important point of reference in the public discourse of interwar Yugoslavia not only because it became a kind of an instrument in the hands of politicians, especially the king, but also - and perhaps primarily - because it grew it roots in the broader social discourse, not only in politics but also in the media and culture - literature or the arts. It is also worth mentioning that the memory of these events was not a homogeneous one. For obvious reasons, it were the Serbs, who excelled in the worship of the Serbian soldiers, who sacrificed their blood for building a common Yugoslav state. While the attitude of Croats and Slovenes was not so clear. Therefore the cult of the Serbian army required an appropriate action from the state. One of the actions was a way of presenting these events in the daily press.

The main aim of the author is to show how the cult of the sacrifice of the Serbian soldiers and civilians during World War I, and especially the mythologized Albanian Golgotha, was created and became one of the pillars on which authorities tried to build a Yugoslav identity and the prestige of the Karađorđević dynasty in the interwar period. A special attention is paid to the way of describing those events in the "Politika" daily, the most read and influential journal of interwar Yugoslavia.
\end{abstract}

Autor: Paweł Michalak, Uniwersytet im. Adama Mickiewicza w Poznaniu, Wydział Historyczny, Instytut Historii, ul. Umultowska 89D, 61-614 Poznań, pawelmaldini@poczta.onet.pl

Słowa kluczowe: Chorwaci i Słoweńcy, Królestwo Jugosławii, Aleksander Karađorđević, I wojna światowa, Albańska Golgota, pamięć zbiorowa, propaganda, prasa

Keywords: Croats and Slovenes, The Kingdom of Yugoslavia, Alexander Karađorđević, World War I, Albanian Golghota, collective memory, propaganda, press

Balcanica Posnaniensia. Acta et studia, XXIII, Poznań 2016, Wydawnictwo Instytutu Historii UAM, pp. 71-108, ISBN 978-83-65663-26-9, ISSN 0239-4278. Polish text with a summary in English.

doi.org/10.14746/bp.2016.23.6 


\section{WPROWADZENIE}

Rozejrzałam się $i$ widziałam jedynie ciemność i smutek [...]. Godzina za godzina, dzień za dniem trwała cisza beznadziei i rozpaczy. Nie było śmiechu, nie było śpiewu, nie byto rozmów. Była to cisza konduktu pogrzebowego, a można by rzec, że w istocie byt to kondukt pogrzebowy ${ }^{1}$.

Tymi słowami Anne Mabel Sinclair Stobart, jedna z wielu Brytyjek działających w Serbskim Funduszu Pomocy (Serbian Relief Fund), czyli organizacji niosącej pomoc humanitarną ludności serbskiej w czasie I wojny światowej, opisała odwrót serbskiej armii przez góry Albanii aż do samego Adriatyku, w którym uczestniczyła zimą $1915 \mathrm{r}^{2}$. Sformułowanie to doskonale odzwierciedlało niemal nabożny stosunek serbskiego społeczeństwa, w którego pamięci zbiorowej exodus ten nieprzypadkowo funkcjonował, i funkcjonuje nadal, jako albańska Golgota. Wydarzenie to było jednym z najważniejszych punktów odniesienia w dyskursie publicznym międzywojennej Jugosławii. Oficjalne czynniki rządowe próbowały przedstawić je, wraz z innymi wydarzeniami I wojny światowej i szeroko rozumianą ofiarą krwi serbskiego żołnierza, jako mit założycielski zjednoczonego państwa jugosłowiańskiego ${ }^{3}$. Mit ten został również zaprzęgnięty do szeroko rozumianej propagandy dynastycznej Karađorđeviciów, poprzez którą król Aleksander Karađorđević (rządzący w latach 1921-1934) próbował wzmocnić zarówno znaczenie dynastii, jak i swoją własną pozycję polityczną.

Po zakończeniu bitwy nad Kolubarą (16 listopada - 15 grudnia 1914 r.), która choć znacząco wykrwawiła serbską armię, to jednak była kolejnym w krótkim okresie zwycięstwem nad zdecydowanie liczniejszą i lepiej wyposażoną armią austrowęgierską (pierwszym była bitwa pod górą Cer, 15-24 sierpnia 1914 r.), doszło do niemal całkowitego wyciszenia walk na serbskim froncie wojny. Sytuacja zmieniła się 5 października 1915 r., gdy rozpoczęła się wspólna ofensywa wojsk AustroWęgier i Niemiec pod dowództwem feldmarszałka Augusta von Mackensena. Gdy 14 października działania te wsparła Bułgaria, los okrążonej Serbii był przesądzony. W związku z kolejnymi sukcesami Państw Centralnych i upadkiem Belgradu, Naczelne Dowództwo serbskiej armii 25 listopada 1915 roku wydało odezwę, w której oznajmiało, że:

Nadszedt czas, kiedy w skutek zaistniałych okoliczności zostaliśmy zmuszeni do wycofania się przez Czarnogórę i Albanię [...]. Kapitulacja byłaby najgorszym możliwym rozwiqzaniem, bo oznaczataby utratę państwa [...]. Jedynym wyjściem z tej ciężkiej sytuacji jest wycofanie się na wybrzeże Adriatyku. Tam nasza armia zostanie zreorganizowana, zaopatrzona w zapasy żywności, broni, amunicji, umundurowania $i$ wszystkich niezbędnych rzeczy, które zostana przestane przez naszych sojusz-

${ }^{1}$ М. Синклер Стобарт, Огњени мач у Србији и другде, Лондон 1916; Р. Дамјановић, Распеће Србије. Страни аутори о Србима и Србији у Великом Рату - савременци, учесници, сведоци, Београд 2014, s. 241.

${ }^{2}$ Więcej o Serbskim Funduszu Pomocy (Serbian Relief Fund) m.in. M. Radovanović, British Medical Missions in Serbia 1914-1915, "London Philatelist", 2012, t. 121, nr 1396, s. 121-129.

${ }^{3}$ V. Drapac, Constructing Yugoslavia. A transnational history, London 2010, s. 96-97. 
ników, po czym znów staniemy się czynnikiem, z którym nasi sprzymierzeńcy będa musieli się liczyć [...]. W tych trudnych dniach, nasze wybawienie leży w naszej wytrzymałości, cierpliwości i wytrwatości nas wszystkich oraz w wierze w ostateczne zwycięstwo naszych sojuszników ${ }^{4}$.

Zgodnie z przyjętymi założeniami, serbska armia miała możliwie szybko zniszczyć, bądź ukryć ciężki sprzęt, by ten nie dostał się w ręce wroga, i wycofać się nad albańskie wybrzeże Adriatyku wzdłuż linii Szkodra - Durrës. Tam też żołnierze mieli otrzymać pomoc i wsparcie państw Ententy, której okręty miały przetransportować armię w bezpieczne miejsce ${ }^{5}$. Dla wielu tą ziemią obiecaną stała się grecka wyspa Korfu. Wędrówka ta prowadząca przez masywy górskie w Czarnogórze i Albanii, w warunkach mroźnej i śnieżnej zimy oraz ataków ze strony oddziałów albańskich ${ }^{6}$, pochłonęła wiele ofiar wśród serbskich żołnierzy i cywili. Wielu, uciekając przed wrogiem, zginęło z wyziębienia, głodu, skrajnego wyczerpania i chorób (jak szacowano, epidemia grypy pochłonęła około 100 tysięcy ofiar wśród cywilów i 35 tysięcy żołnierzy) ${ }^{7}$.

Ostatecznie, w połowie stycznia do albańskich wybrzeży Adriatyku przedostało się około 145 tysięcy żołnierzy i 5 tysięcy cywili ${ }^{8}$. Natomiast dokładna liczba ofiar tych wydarzeń wciąż budzi wątpliwości. Szacuje się, że wszystkie potyczki zbrojne od początku 1915 r., wraz z migracją nad Adriatyk, pochłonęły życie około 250 tysięcy serbskich żołnierzy i 140 tysięcy cywili ${ }^{9}$. Trudniejsza do ustalenia jest liczba ofiar samej przeprawy przez góry Albanii. W serbskiej historiografii brak zgody co do ostatecznej liczby zmarłych, a szacunki te zamykają się w szerokim przedziale od 70 do nawet 225 tysięcy $^{10}$. Wydaje się jednak, że najbardziej prawdopodobna liczba ofiar albańskiej Golgoty wynosi od 70 do 150 tysięcy osób ${ }^{11}$. Należy pamiętać, że liczba ta jest umowna, bowiem exodus ten zbierał tragiczne żniwo jeszcze wiele miesięcy

${ }^{4}$ A. Mitrović, Serbia's Great War, 1914-1918, West Lafayette 2007, s. 149; W. Szczepański, Serbski odwrót przez Albanię na przełomie 1915/1916 roku Jak doń doszło, jak zapamiętali go Serbowie?, w: I wojna światowa na Bałkanach. Działania militarne i polityczne w latach 1914-1918, red. A. Krzak, Szczecin 2014, s. 226.

${ }^{5}$ М. Радојевић, љ. Димић, Србија у Великом Рату 1914-1918, Београд 2014, s. 183; М. Ж. Живановић, О евакуащији српске војске из Албаније и њеној реорганизацији на Крфу (1915-1916) према франиуским документима, „Историјски часопис”, 1963-1965, t. 14-15, s. 234-235.

${ }^{6}$ Warto w tym miejscu podkreślić, że nie wszystkie albańskie oddziały zbrojne napotkane w trakcie tej przeprawy prezentowały wrogi stosunek do Serbów. Mowa np. o grupach podlegających Esadowi Paszy Toptaniemu, który współpracował z rządem Nikoli Pašicia. Więcej o tym: T. Czekalski, Układ Toptani - Pašić i jego następstwa. Relacje albańsko-serbskie w pierwszym roku Wielkiej Wojny, w: I wojna światowa na Batkanach, s. 37-51.

${ }^{7}$ M. Bokovoy, Scattered graves. Commemorating Serbia's Wars of National Liberation, 19121918, w: Staging the Past: The Politics of Commemoration in Habsburg Central Europe, 1848 to the Present, red. M. Bucur, N. Wingfield, West Lafayette 2001, s. 238.

${ }^{8}$ D. T. Bataković, Serbia 1914-1918: War imposed, martyrdom, resurrection, w: Serbia in the Great War. Anglo-Saxon Testimonies and Historical Analysis, red. D. T. Bataković, Belgrade 2015, s. 32; М. Ж. Живановић, op. cit., s. 242-243.

9 М. Радојевић, Љ. Димић, ор. cit., s. 189.

10 Szerzej o tej kwestii pisał W. Szczepański, op. cit., s. 228.

11 A. Mitrović, op. cit., s. 152; М. Ж. Живановић, op. cit., s. 242-243. 
po jego zakończeniu. Bardzo wielu rannych, wygłodzonych, skrajnie wycieńczonych żołnierzy i cywili zmarło po dotarciu na Korfu, a tysiące zaginionych nigdy nie wróciło do domów ${ }^{12}$. Jednym z najbardziej szokujących elementów tej statystki jest to, że spośród 6 tysięcy rekrutów urodzonych w latach 1897-1898, a więc ówczesnych 17 i 18-latków, wydarzenia z zimy przełomu 1915 i 1916 roku przeżyło jedynie pięciuset $^{13}$. Komentując tę statystykę, król Piotr Karađorđević miał stwierdzić ze smutkiem, że nawet jeśli w przyszłości Serbia będzie jeszcze istnieć, to boi się, czy będa dla niej żyli jeszcze jacyś Serbowie ${ }^{14}$. Sformułowanie to w sposób dobitny podkreśla, jak wielkim poświęceniem, ofiarą i heroizmem wykazali się wszyscy, którzy zdecydowali się podjąć ryzyko wędrówki przez albańskie góry.

I wojna światowa a wraz z nią także i albańska Golgota, w okresie dwudziestolecia międzywojennego urosły do rangi mitów o dwojakiej percepcji. Przede wszystkim uznano je za mity założycielskie Królestwa Serbów, Chorwatów i Słoweńców (od 1929 roku Królestwa Jugosławii). Zgodnie z tą optyką, państwo jugosłowiańskie powstało w następstwie wydarzeń wojennych i przelaniu serbskiej krwi. Upamiętnienie tragicznych wydarzeń z czasu I wojny światowej miało służyć tworzeniu podwalin tożsamości jugosłowiańskiej. Wedle innej interpretacji, przekazy na temat albańskiej Golgoty były nakierowane na umocnienie prestiżu dynastii Karađorđeviciów zarówno w oczach Serbów, jak i w ramach całego państwa jugosłowiańskiego. Poprzez podkreślanie roli króla Piotra i jego syna oraz następcy tronu Aleksandra w wydarzeniach wojennych usiłowano ugruntować wśród poddanych przywiązanie do elity rządzącej. I tak, w narracjach o wydarzeniach z 1915 roku wielokrotnie podkreślano, że 70-letni król Piotr i jego syn nie porzucili swojej armii w godzinie dramatycznej próby, ale ramię w ramię przebyli z nią cały szlak bojowy, dzieląc trudy wędrówki. Takie przedstawienie faktów stanowiło nadinterpretację, ponieważ regent Aleksander w zasadzie nie maszerował razem z armią, a i Piotr przebył tę trasę znacznie szybciej od serbskich oddziałów, ponieważ dotarł do albańskiej Lezhy już na początku grudnia ${ }^{15}$. W przypadku Aleksandra podróż trwała jeszcze krócej, gdyż już 1 grudnia został zakwaterowany w Szkodrze ${ }^{16}$. O ile zadbanie o bezpieczeństwo najważniejszych polityków w kraju nie powinno budzić zdziwienia, o tyle rozwijanie mitu wspólnej tułaczki stanowi celową nadinterpretację. Jej celem było zbudowanie silnej

12 Dušan Bataković twierdzi, że w związku z tym liczba ofiar albańskiej Golgoty wzrosła do prawie 250 tysięcy; D. T. Bataković, op. cit., s. 32.

${ }^{13}$ A. Mitrović, op. cit., s. 152.

14 Д. Шаренац, Топ, војник и сећање. Први светски рат и Србија 1914-2009, Београд 2014, s. 137.

15 П. Карађорђевић, Ратни дневник 1915-1916 (приредио и предговор написао др Драгљуб Р. Живојиновић), Београд 1984, s. 151.

16 Regent Aleksander w zasadzie nie doświadczył trudów albańskiej Golgoty. Przybył on do albańskiej Szkodry 1 grudnia 1915 roku. Wcześniej, bo 28 listopada, pojawili się tam przedstawiciele rządu serbskiego. Z kolei główne dowództwo armii serbskiej wyruszyło w stronę Szkodry 26 listopada, aby osiągnąć to miasto 6 grudnia. Б. Глигоријевић, Краљ Александар Карађорђевић, Београд 2010, s. 185; A. Mitrović, op. cit., s. 151; М. Радојевић, љ. Димић, ор. cit., s. 186-187. 
więzi między domem królewskim a poddanymi. Nie ulega jednak wątpliwości, że zapewne również dzięki tego typu zabiegom - narracja o albańskiej Golgocie bardzo szybko zakorzeniła się w dyskursie publicznym międzywojennej Jugosławii.

\section{ŚLADY W KULTURZE}

Pamięć o heroizmie i poświęceniu serbskiej armii w czasie Wielkiej Wojny umacniała się w licznych wierszach (np. Plava Grobnica Milutina Bojića), powieściach (m.in. Dan Šesti Rastko Petrovića, Groblje bez krstova Miroslava Golubovicia, Vreme smrti Dobricy Ćosicia), czy też popularnych pieśniach (Tamo,daleko) ${ }^{17}$. Utrwalany w jugosłowiańskiej - w tym przede wszystkim serbskiej - literaturze mit albańskiej Golgoty, z czasem zrósł się z mitami kosowskim i wielkich wędrówek Serbów (seobe). Został wpisany w narrację o poświęceniu serbskiego narodu, jego niezłomności i dążeniu do ostatecznego zwycięstwa ${ }^{18}$. Mistyczny odbiór wydarzeń I wojny światowej, w tym także albańskiej Golgoty, obecny w dyskursie publicznym międzywojennej Jugosławii, interesująco przedstawiła serbska historyk Olga ManojlovićPintar ${ }^{19}$. Według niej, wydarzenia z roku 1915, gdy Serbia została zaatakowana przez Niemcy, Austro-Węgry i Bułgarię, były interpretowane w duchu biblijnej walki między Dawidem a Goliatem. Wkroczenie Bułgarii do wojny z Serbią ukazywano jako ,judaszową zdradę", a dramatyczne przejście wojsk serbskich przez ziemie albańskie jako Golgotę. I dalej, zwycięstwa odnoszone przez wojska serbskie na froncie salonickim (1917-1918) ukazywano w duchu zmartwychwstania narodu serbskiego i ucieleśnienia idei wspólnoty jugosłowiańskiej ${ }^{20}$.

Pamięć o tragizmie albańskiej Golgoty upamiętniano również w innych dziedzinach kultury. Powodzeniem cieszyły się wystawy obrazów i zdjęć przywołujących te wydarzenia. Wspomnieć należy zwłaszcza o fotogramach autorstwa Riste Marjanovića, jednego z pierwszych serbskich fotoreporterów. Jego prace uwieczniające wydarzenia związane z albańska Golgota były wielokrotnie reprodukowane na kartach pocztowych, także z myślą o propagowaniu serbskiego poświęcenia na rzecz wolności narodów południowosłowiańskich. Większość reprodukcji przynosiła sceny marszu z udziałem wycieńczonych żołnierzy i króla Piotra, który miał im towarzyszyć.

\footnotetext{
${ }^{17}$ Więcej o percepcji Wielkiej Wojny przez kulturę jugosłowiańską: J. Milojković-Djurić, Great War legacies in Serbian Culture, „Balcanica”, 2015, R. 46, s. 241-254.

${ }^{18}$ Patrz m.in. B. Zieliński, Serbska powieść historyczna. Studia nad źródłami, ideami i kierunkami rozwoju, Poznań 1998, s. 185-186, 189, 191-192, 230-235, 246. Kwestię tę porusza również W. Szczepański, op. cit., s. 227-228.

${ }^{19}$ Patrz m.in. О. Манојловић-Пинтар, „Благо и њима јер су славно пали за отаибину, краља и слобоу": култ палих војника у Италији и Југославији у годинама између два светска рата, „Годишњак за друштвену историју”, 2002, t. 9, nr 1-3, s. 79-98.

${ }^{20}$ P. Troch, Education and Yugoslav Nationhood in Interwar Yugoslavia. Possibilities, limitations and interactions with other national ideas, Gent 2012, [niepublikowana praca doktorska], s. 253-254.
} 
Warto zwrócić uwagę, że w głównym, wspieranym przez państwo nurcie kultury międzywojennej, odwołującym się do pamięci o I wojnie światowej, próżno szukać twórczości o charakterze pacyfistycznym, charakterystycznej dla kultury zachodnioeuropejskiej ${ }^{21}$. W jugosłowiańskim dyskursie publicznym dominowało przedstawianie wydarzeń Wielkiej Wojny w kontekście olbrzymiego poświęcenia Serbów w imię odrodzenia narodowego, a także stworzenia zjednoczonego państwa jugosłowiańskiego. Dobitnym przykładem braku akceptacji władz dla pacyfistycznej negacji czasów wojennych, był zakaz wyświetlania na Królestwie Jugosławii filmu Na Zachodzie bez zmian w reżyserii Lewisa Milestone'a, na podstawie książki Erica Marii Remarqu'a ${ }^{22}$. Obraz I wojny światowej, w tym również albańskiej Golgoty należało przedstawiać tylko w jeden, pożądany przez władze sposób ${ }^{23}$.

\section{„POLITYKA PAMIĘCI”}

Ofiary i poświęcenie serbskiej armii podczas I wojny światowej, w tym odwrót przez góry Albanii, stały kluczowym mitem założycielskim dla Królestwa SHS, wielokrotnie wykorzystywanym do celów politycznych ${ }^{24}$. Zarówno rząd, jak i król Aleksander (de facto rządzący od 1914 roku jako regent Królestwa, a od sierpnia 1921 roku jako król Królestwa SHS) chętnie odwoływali się do tych wydarzeń. Nawiązywano do nich przy okazji różnych uroczystości, obchodów rocznicowych, dotyczących zarówno wojny, jak i okoliczności stworzenia Jugosławii. Podkreślano, że wojenne bohaterstwo serbskich żołnierzy i wylana przez nich krew były ofiarami złożonymi na ołtarzu ojczyzny „trójimiennego” narodu, jak określano Serbów, Chorwatów i Słoweńców. Po wprowadzeniu dyktatury królewskiej 6 stycznia 1929 roku, koncept „trzech plemion tego samego narodu” został zastąpiony ideą integralnego jugoslawizmu.

O dużym znaczeniu albańskiej Golgoty i jej miejscu w pamięci społecznej może świadczyć decyzja o przyznawaniu specjalnego orderu wszystkim uczestnikom tych wydarzeń. Mowa o odznaczeniu Albanska spomenica, ustanowionym przez regenta Aleksandra Karađorđevicia 5 kwietnia 1920 roku $^{25}$. Honorowano nim wszystkich

${ }^{21}$ Patrz m.in. J. Winter, Sites of Memory, Sites of Mourning. The Great War in European cultural history, Cambridge 1995.

${ }^{22}$ Архив Југославије [dalej AJ], 38-244-392.

${ }^{23}$ Analizując ówczesną prasę doskonale widać, że pamięć o I wojnie światowej układała się w dwie narracje. Dominujące w przestrzeni publicznej serbskie gazety, dzienniki i periodyki celebrowały rocznice związane z wydarzeniami z lat 1914-1918 (a także z okresu wojen bałkańskich 1912-1913). Ich chorwackie odpowiedniki niewiele pisały na ten temat. Co więcej zdarzało się, że opisywały te wydarzenia w duchu pacyfistycznym, co było źle odbierane przez władze centralne; M. Czerwiński, Chorwacki bóg Mars i serbska Golgota, „Herito”, 2014, R. 3, nr 16, s. 60-63.

${ }^{24}$ V. Drapac, Constructing Yugoslavia, s. 96-97.

25 Д. Грбовић, Одликовања Краљевине Србије и Краљевине Срба, Хрвата и Словенаиа установљена поводом првог светског рата из збирке завичајног музеја у Јагодини, „Корени. Историјски Архив Јагодине", 2008, t. 6, s. 80-81. 
uczestników albańskiej Golgoty, żołnierzy, towarzyszących im przedstawicieli zagranicznych misji wojskowo-dyplomatycznych oraz cywili ${ }^{26}$. Medale były wręczane podczas uroczystych akademii i świąt państwowych. Warto przyjrzeć się formie tego odznaczenia. Poza nawiązaniem do serbskiego dwugłowego orła, uwagę przykuwa profil regenta Aleksandra z napisem Swoim towarzyszom broni - Aleksander. Na rewersie zaś wygrawerowano: Za wierność ojczyźnie, 1915. Taka forma odznaczenia państwowego miała na celu skrócenie dystansu emocjonalnego między następcą tronu a poddanymi dynastii serbsko-jugosłowiańskiej. Pamiętajmy, że order został ustanowiony, gdy władcą Królestwa SHS pozostawał król Piotr. Bez wątpienia Albanska spomenica służyła legitymizacji Aleksandra jako pełnoprawnego władcy państwowego. W jego wizerunku akcentowano wojskowe, wojenne zasługi regenta. Order był przyznawany każdemu, kto przeżył albańska Golgotę, niezależnie od tego, czy był oficerem, szeregowym żołnierzem czy cywilem, a następca tronu zdawał się utożsamiać z ich losem. Identyfikował się z wydarzeniami 1915 roku, choć jak wiemy, nie asystował on „towarzyszom broni” w najtrudniejszych momentach górskiej przeprawy, przebywając już wtedy nad Adriatykiem.

Pamięć o albańskiej Golgocie była również wykorzystywana, jako swego rodzaju legitymizacja działań króla Aleksandra, który część swych decyzji politycznych uzasadniał podkreślając, że poświęcenie i krew żołnierza serbskiego, przelana za zjednoczone Królestwo SHS, jak i wszystkich jego obywateli nie mogła pójść na marne. W słynnej odezwie Mome dragom narodu z 6 stycznia 1929 r., w której władca ten informował poddanych o wprowadzeniu dyktatury, uzasadniając swą decyzję stwierdził, że: stanie na straży jedności narodu i całego kraju, to jest najważniejsze zadanie Moich Rzadów [...]. Tego wymaga moja mitość do Ojczyzny i szacunek względem niezliczonych, drogocennych ofiar, które zginęty dla tego ideatu ${ }^{27}$. Usprawiedliwiając tę decyzję, władca miał stwierdzić w rozmowie z Nikolą Uzunovićem, że wprowadzenie dyktatury w celu utrzymania jedności Królestwa było jego świętym obowiązkiem, do którego realizacji był w tym trudnym momencie zobowiązany poprzez ślubowanie, złożone poległym w bitwie nad Kolubarą, w czasie albańskiej Golgoty i bitwy pod górą Kajmakczalan ${ }^{28}$. W ten sposób pamięć o ofiarach przeprawy przez Albanię, stała się argumentem dla działań na gruncie polityki wewnętrznej Królestwa. Nie będzie przesadą stwierdzenie, że w czasach dyktatury królewskiej (1929-1924) w zasadzie w każdym przemówieniu króla lub innego przedstawiciela władz odwoływano się do ofiary przodków, którzy poświęcili życie na ołtarzu walki o wspólną ojczyznę Jugosłowian ${ }^{29}$. Stałym punktem oficjalnych spotkań politycznych w w Belgradzie, było składanie kwiatów przed Grobem Nieznanego Żołnierza na wzgórzu Avala oraz

26 Ibidem.

27 „Политика”, 1929, nr 7430, 06.01.1929, s. 1.

${ }^{28}$ Ch. A. Nielsen, Making Yugoslavs: Identity in King Aleksandar's Yugoslavia, Toronto 2014, S. 155 .

29 Ibidem. 
przed grobowcem Piotra Karađorđevicia, „Wielkiego Wyzwoliciela” w Oplenacu ${ }^{30}$. Przy każdej z tych okazji upamiętniano ofiary albańskiej Golgoty.

O tym, jak bardzo albańska Golgota zakorzeniła się w serbskiej a także jugosłowiańskiej pamięci zbiorowej świadczy fakt, że nawiązywano do niej również przy innych, tylko teoretycznie niepowiązanych rocznic i obchodów. Przykładem niech posłuży wieś Dulgovac, w której po wojnie odsłonięty został pomnik upamiętniający 410 serbskich cywili i trzech księży, zamordowanych podczas bułgarskiej okupacji. Co ciekawe, monument upamiętniał również Serbów, którzy zginęli podczas wędrówki przez góry Albanii. Jeden z umieszczonych na nim napisów brzmiał:

Niestety, nie istnieje wystarczająco dużo cmentarzy i pomników upamiętniajacych wydarzenia, w których większość ofiar padła z rąk wrogów, głodu, wycieńczenia, śniegu i mrozu. Niezliczona ilość grobów pozostaje rozsiana wzdluż skalistych szlaków [...] i dzisiaj nie ma żadnych znaków [przypominajacych o tych - P.M.], którzy tam zginęli. [Jednak-P.M.] Wieczne i żywe wspomnienia tych strasznych, ale wielkich dni przetrwaja ${ }^{31}$.

Jak widać, albańska Golgota stanowiła ważny element dyskursu publicznego międzywojennej Jugosławii nawet na poziomie małych, wiejskich społeczności lokalnych. Należy jednak pamiętać, że przekaz ten funkcjonował głównie w społecznościach serbskich, identyfikujących się z losami żołnierzy swojego kraju. Dla większości przedstawicieli pozostałych narodów królestwa, Chorwatów i Słoweńców, wydarzenia te nie niosły ze sobą tak dużego ładunku samoidentyfikacji. Chcąc uzyskać pożądany odbiór tych wypadków, zarówno król Aleksander i przedstawiciele poszczególnych rządów jugosłowiańskich starali się wypracować swoisty ton narracji o albańskiej Golgocie. Świadczą o tym liczne brudnopisy przemówień i tekstów przygotowywanych z okazji różnych rocznic historycznych, opracowywane za czasów dyktatury królewskiej przez Centralne Biuro Prasowe ${ }^{32}$. Organ ten nadzorował i kontrolował prasę, będąc de facto ministerstwem cenzury i propagandy ${ }^{33}$. Zdawano sobie sprawę, że modelowanie przestrzeni publicznej byłoby niemożliwe bez wsparcia prasy, która w dwudziestoleciu międzywojennym była najbardziej opiniotwórczą formą przekazu medialnego. Warto więc zwrócić uwagę, w jaki sposób albańska Golgota przedstawiana była na łamach najważniejszego jugosłowiańskiego dziennika tamtych czasów - tj. „Politiki”.

${ }^{30}$ I. Meštrović, Uspomene na političke ljude i događaje, Zagreb 1993, s. 215-222; Ch. A. Nielsen, Making Yugoslavs, s. 156; A. B. Wachtel, Making a Nation, Breaking a Nation: Literature and Cultural Politics in Yugoslavia, Stanford 1998, s. 265.

${ }^{31}$ M. Bokovoy, op. cit., s. 246.

32 Centralni Presbiro.

${ }^{33}$ AJ, 38-99-233; 335-76+107. 


\section{NARRACJA ,POLITIKI”}

Dziennik „Politika” powstał 25 stycznia 1904 roku w Belgradzie, a jego założycielem był Vladislav Ribnikar. Była to jedna z najstarszych i najbardziej prestiżowych gazet codziennych na Bałkanach, a w okresie rządów króla Aleksandra Karađorđevicia uchodziła za najbardziej opiniotwórcze czasopismo w Królestwie Jugosławii ${ }^{34}$. Nie ulega wątpliwości, że dziennik ten może być uznawany za swoiste lustro, w którym odbijały się polityczne koncepcje króla Aleksandra, gdyż mimo głoszonej powszechnie apolityczności, linia pisma niemal zawsze odpowiadała linii politycznej władcy ${ }^{35}$.

O albańskiej Golgocie na łamach „Politiki” pisano z mniejszym lub większym natężeniem przez całe dwudziestolecie międzywojenne. Analizując ten organ prasowy pod tym właśnie kątem można wyodrębnić trzy sposoby pisania o wydarzeniach z zimy 1915-1916. W pierwszym podkreślano zasługi i poświęcenie dynastii Karađorđeviciów, przede wszystkim króla Piotra, który pomimo podeszłego wieku, w chwili największej próby nie opuścił swych poddanych. W drugim akcentowano kult ofiary serbskich żołnierzy, ich poświęcenia dla wszystkich (co podkreślano szczególnie) Jugosłowian. W trzecim nurcie umieścić należy odwoływanie się do wojennych wydarzeń przy opisie i komentowaniu bieżącej sytuacji politycznej w Jugosławii.

Dnia 24 września 1919 roku $^{36}$, w niecały miesiąc po powojennej reaktywacji dziennika, „Politika” opublikowała artykuł, w którym przybliżała postać króla Piotra, w tym jego przemowę wygłoszoną w czasie przebijania się przez zaśnieżone góry Albanii ${ }^{37}$. Władca królestwa został przedstawiony jako troskliwy ojciec, podnoszący na duchu swoje dzieci - Nie bójcie się, nie poddawajcie - miał mówić król - to wszystko przeminie. I stuchajcie mnie! Ja stary, doczekam naszego powrotu, do mego pięknego Belgradu. A wy, wy młodzi, wy ujrzycie dni o których nam się nie śniło [...]. Jak podkreślono, słowa te stanowiły otuchę dla uciekinierów, którzy kolejną noc spędzili w towarzystwie króla Piotra, jednego ze swoich towarzyszy niedoli ${ }^{38}$. Cechą charakterystyczną w opisywaniu roli i postawy króla w czasie albańskiej Golgoty było podkreślanie jego niezłomności, poświęcenia i dzielenia losu zwykłych żołnierzy, pomimo podeszłego już wieku. Objawiało się to chociażby w notatce informacyj-

${ }^{34}$ Pod koniec lat dwudziestych „Politika” była tytułem o największym dziennym nakładzie, wynoszącym około 75 tysięcy egzemplarzy (60 tysięcy w przypadku „Vreme” i 25 tysięcy w przypadku „Pravdy”). W kolejnych latach dystans między nią a konkurencją stale się powiększał. W 1941 roku nakład wyniósł 145700 egzemplarzy, przy 65 tysięcy „Vreme” i 45 tysięcy „Pravdy”; M. Bjelica, 200 godina jugoslovenske štampe. Pregled istorije novinarstva, Beograd 1968, s. 165; Ch. A. Nielsen, One State, One Nation, One King: The Dictatorship of King Aleksandar and his Yugoslav Project 1929-1935, Columbia University 2002 [niepublikowana praca doktorska], s. 337.

35 Ibidem.

36 „Политика”, 1919, nr 4182, 24.09.1919, s. 1.

37 Tekst ten przedrukowano również 21 sierpnia 1921 roku po śmierci monarchy; „Политика”, 1921 , nr 4786, 21.08.1921, s. 5.

38 „Политика”, 1919 , nr 4182, 24.09.1919, s. 1. 
nej o wystawie fotografii Risty Marjanovicia, opublikowanej 20 stycznia 1926 roku Opisując zdjęcia przedstawiające króla Piotra dziennikarz stwierdził: Każda fotografia powie Wam wiele, bardzo wiele. A tutaj widzicie nadludzkie wysitki Starego Króla, dzielacego los swojego narodu $u^{39}$. Estyma, jaką darzono „starego króla” jest jedną z bardziej charakterystycznych cech w sposobie przedstawiania albańskiej Golgoty przez „Politikę”. Dużo miejsca poświęcono królowi w 1925 r., gdy w serii artykułów pod tytułem Przed dziesięciu laty przypominano wydarzenia z roku 1915. W tekście z 24 grudnia 1925 roku, pt. Król Piotr na Ćafa-Malitu przytoczona została przytoczona ciekawie skonstruowana historia ${ }^{40}$. W czasie przeprawy przez góry na pograniczu czarnogórsko-albańskim, na wysokości 2 tysięcy metrów, jeden z oddziałów wojska serbskiego zastała noc. Leżał śnieg, padał marznący deszcz. Wycieńczeni żołnierze cudem natrafili na tlące się palenisko. Gdy okazało się, że pilnowali go Czarnogórcy, Serbowie poprosili ich o jedzenie. Początkowo miejscowi zarzekali się, że nie mieli nawet chleba i ziemniaków. Usłyszawszy zapewnienie serbskich oficerów, że za wszystko zapłacą, Czarnogórcy wyciągnęli ze skrytek worki z ziemniakami i mąką kukurydzianą oraz ser. Podsumowując tę opowieść, autor tekstu nie omieszkał stwierdzić, że jedzenie zostało opłacone za pomocą srebrnych dinarów króla Piotra, które po raz kolejny uratowały życie wielu osobom ${ }^{41}$. Niezwykłość tej historii wynika z jej niedoprecyzowania. Trudno stwierdzić, czy autor miał na myśli to, że za jedzenie Serbowie zapłacili dinarami z wizerunkiem króla, czy chodziło raczej o pieniądze, które zarobili w służbie królowi. A może czytelnik powinien domniemywać, że serbski oddział podróżował z królem, który za wszystko zapłacił z własnej kiesy. Nie było wątpliwości, co do ostatecznej interpretacji tych wydarzeń - to dzięki królowi nikt tej mroźnej i śnieżnej nocy nie zginął. Dzięki władcy wszyscy najedli się do syta, biesiadowali, a potem zapadli w głęboki sen. Idealnym podkreśleniem tej radości i wysiłku zarazem, było zdanie starej Czarnogórki, przytoczone pod koniec tekstu: Patrzcie jak śpia, jak dzieci! Eh ilu was już tędy przeszło! Ilu z Was drzemało przy moim ogniu, ilu podobnych Wam spało niczym dzieci ${ }^{42}$.

$\mathrm{Z}$ biegiem czasu, w narracji o bohaterskim królu Piotrze coraz częściej pojawia się osoba króla Aleksandra. I tak, w artykule z 11 listopada 1930 roku, zatytułowanym Nasza Golgota i szlachetność naszych sojuszników, zamieszczono zdjęcia obu władców z podpisem Król Piotr Wielki Wyzwoliciel oraz Jego Wysokość Król Aleksander ${ }^{43}$. Autor tekstu sugerował, że dzięki osobistemu udziałowi władców w przeprawie góry albańskie, serbskiej armii udało się przetrwać najtrudniejsze chwile:

Kiedy szliśmy przez Albanię, nie wiedzieliśmy dokąd idziemy i co nas tam czeka. Ale byli z nami [...] nasz rycerski Główny Komendant [w domyśle regent Aleksander - P.M.] i nieśmiertelny Wielki Król [w domyśle król Piotr - P.M.]. [...] Szliśmy tak, głodni, spragnieni, nadzy i bosi. Dokad? Tego nie

\footnotetext{
39 „Политика”, 1926, nr 6372, 20.01.1926, s. 4.

40 „Политика”, 1925, nr 6347, 24.12.1925, s. 4.

41 Ibidem, s. 4.

42 Ibidem, s. 4.

43 „Политика”, 1930, nr 8088, 11.11.1930, s. 3.
} 
wiedzial nikt z nas. [...] ale szliśmy przez tę ciężka i krwawa Golgotę, licząc, że gdzieś tam czeka na nas Zmartwychwstanie. Że będziemy zbawieni. I zaiste, Zbawienie to stało się faktem ${ }^{44}$.

Ciekawy przykład wzmacniania pozycji politycznej króla Aleksandra za pomocą odniesień do albańskiej Golgoty stanowi artykuł z 17 grudnia 1922 roku pt. Niech żyje król! ${ }^{45}$. Autor, Dragutin Milosavljević przytoczył w nim historię z 17 grudnia 1915 roku, gdy jego oddział pokonywał góry patrolowane przez wrogie oddziały albańskie. Zapadł zmrok i żołnierze rozglądali się za miejscem na nocleg. W tym celu postanowiono pokonać rwącą rzekę. Jedenastu żołnierzy, dowodzonych przez niejakiego kaprala Branka, starało się przedostać na drugi brzeg. Niestety, w trakcie przeprawy żołnierzy porwał prąd rzeki. Ponieważ byli w pełnym ekwipunku, utonęli. Przed śmiercią nie wołali o pomoc, ale mieli wykrzyknąć: Niech żyje król. Obserwujących ich kompani - bezradni świadkowie dramatu - oddali hołd tonącym, podejmując ten sam okrzyk ${ }^{46}$. Opowieść podkreśla postawę żołnierzy, którzy byli gotowi poświęcić dla towarzyszy broni i króla. Nie bez znaczenia jest data publikacji tego tekstu. Dnia 17 grudnia w państwie jugosłowiańskim uroczyście świętowano urodziny króla Aleksandra Karađorđevicia.

Odwoływanie się na łamach „Politiki” do albańskiej Golgoty nierzadko stanowiło zabieg retoryczny, stosowany w tekstach na temat bieżącej sytuacji politycznej w państwie. Jednym z przykładów jest tekst zatytułowany W istocie Golgota, w którym anonimowy autor opisywał problemy w układaniu interesów Serbów, Chorwatów i Słoweńców, budowaniu struktur Królestwa i przezwyciężaniu tradycyjnych podziałów etnicznych. Artykuł kończyła następująca uwaga:

Braciom Chorwatom i Stoweńcom, jak i nam Serbom pozostaje jedynie pociecha, żeby tę nasza wspólną Golgotę cierpliwie przeczekać i doczekać naszego wskrzeszenia. A do niego dojdzie, ponieważ w końcu żadna Golgota nie trwała wiecznie ${ }^{47}$.

Do cierpienia i poświęcenia serbskiej armii w czasie I wojny światowej odwoływano się także w 1932 roku komentując tzw. ,punktacje zagrzebskie" ${ }^{48}$. I tak, w tekście Powrót do lat minionych, opublikowanym 26 listopada 1932 roku autor krytykował wspólny dokument partii chorwackich. Podkreślał, że ich intencją było cofnięcie się do 1918 roku, a to oznaczałoby, jego zdaniem, zaprzepaszczenie wysiłku podjęte-

44 Ibidem, s. 3.

45 „Политика”, 1922, nr 5263, 17.12.1922, s. 7.

46 Ibidem, s. 7.

47 „Политика”, 1923, nr 5474, 22.07.1923, s. 1.

48 Mianem „punktacji zagrzebskich” określa się rezolucję ogłoszoną 7 listopada 1932 roku przez przedstawicieli Koalicji Chłopsko-Demokratycznej (składającej się z Chorwackiej Partii Chłopskiej i Niezależnej Partii Demokratycznej), w której potępiono królewską dyktaturę, jako narzucenie serbskiej hegemonii pozostałym nacjom zamieszkującym Królestwo Jugosławii. Jednym z głównych postulatów tej rezolucji był powrót do stanu z grudnia 1918 roku i dokonanie reorganizacji państwa w duchu federalistycznym, z odejściem od polityki centralizmu i unitaryzmu oraz przyznaniem dużej autonomii poszczególnym członom królestwa; L. Benson, Jugosławia. Historia w zarysie, Kraków 2011, s. 76-77; W. Walkiewicz, Jugostawia. Państwa sukcesyjne, Warszawa 2009, s. 89-91. 
go w trakcie całej ostatniej dekady. W opinii dziennikarza, nie wolno było zapomnieć o męczeństwie bohaterów wojennych o przelanej przez nich krwi, która stanowiła zaczyn państwa jugosłowiańskiego. Jak podkreślał autor artykułu, powstanie Jugosławii było możliwe tylko dzięki ofierze z krwi i wojennemu bohaterstwu ${ }^{49}$. Z kolei w tekście autorstwa Viktora Novaka z 1 grudnia 1932 r., zatytułowanym Pierwszy grudnia $w$ świetle prawdy historycznej, a wydrukowanym z okazji przypadających tego dnia obchodów tzw. Dnia Zjednoczenia, autor uznał, że powstanie wspólnego państwa Jugosłowian byłoby niemożliwe, gdyby nie:

Nieopisana hekatomba najkrwawszych ofiar, najcięższy wysiłek fizycznej $i$ duchowej walki, straszne cierpienia i upokorzenia. Przeszliśmy przez gehennę Golgoty historii narodowej, ale dotrwaliśmy do dni narodowego Wskrzeszenia ${ }^{50}$.

Po raz kolejny albańska Golgota posłużyła jako argument usprawiedliwiający kurs polityki wewnętrznej państwa, obrany przez władze królewskie.

\section{ZAKOŃCZENIE}

Pamięć o albańskiej Golgocie była bardzo żywa nie tylko w dyskursie historycznym międzywojennej Jugosławii. Doświadczenie exodusu wojsk serbskich z 1915 roku wryło się w pamięć zbiorową serbskiego społeczeństwa, stając się doświadczeniem ogólnonarodowym, o masowym charakterze. Trudno było znaleźć rodzinę, w której choć jedna osoba nie brała udziału w tragicznych wydarzeniach z 1915 roku. Wspominali je bezpośredni uczestnicy oraz ich krewni. Zdarzenia te funkcjonowały w przestrzeni publicznej w wielu postaciach. Władze Królestwa starały się ukierunkować pamięć i sposób myślenia o tych zdarzeniach tak, aby wzmocnić ideę jugosłowiańską oraz autorytet polityczny dynastii Karađorđeviciów - głównego spoiwa państwa jugosłowiańskiego. Niestety, szybko okazało się, że pamięć ta była kultywowana tylko przez Serbów i w pewnym stopniu przez Czarnogórców ${ }^{51}$. Chorwaci czy Słoweńcy nie chcieli nawiązywać do tego wspomnienia, tak jak i nie identyfikowali z większością wojennych doświadczeń Serbów. W optyce tych społeczności, za kultem ofiary i poświęcenia serbskiej armii, przedstawianym przez propagandę jako jeden z filarów międzywojennej Jugosławii, stały próby uznania Serbów za pierwszych pośród równych $\mathrm{w}$ państwie ${ }^{52}$.

Ostatecznie to nie Wielka Wojna, albańska Golgota i jej ofiary, ale działalność partyzantki komunistycznej w czasach II wojny światowej wryła się w pamięć szer-

${ }^{49}$ Ch. A. Nielsen, Making Yugoslavs, s. 155.

50 „Политика”, 1932, nr 8822, 01.12.1932, s. 1.

${ }^{51}$ P. Troch, Nationalism and Yugoslavia. Education, Yugoslavism and the Balkans before World War II, London 2015, s. 91.

${ }^{52}$ M. Bokovoy, op. cit., s. 251-252. 
szych kręgów jugosłowiańskiego społeczeństwa. Ruch jugosłowiański w wydaniu komunistycznym z powodzeniem wprowadził do pamięci zbiorowej narodów południowosłowiańskich wspólnotowe doświadczenie wojenne, odwołując się ponadnarodowego hasła Braterstwo i jedność (Bratstvo i jedinstvo) ${ }^{53}$. Oczywiście, z czasem i ten koncept został zanegowany.

\section{BIBLIOGRAFIA}

Bataković Dušan T., Serbia 1914-1918: War imposed, martyrdom, resurrection, w: Serbia in the Great War. Anglo-Saxon Testimonies and Historical Analysis, red. D. T. Bataković, Belgrade, 2015, s. 9-36.

Benson Leslie, Jugosławia. Historia w zarysie, Kraków, 2011.

Bjelica Mihailo, 200 godina jugoslovenske štampe. Pregled istorije novinarstva, Beograd 1968.

Bokovoy Melissa, Scattered graves. Commemorating Serbia's Wars of National Liberation, 1912-1918, w: Staging the Past: The Politics of Commemoration in Habsburg Central Europe, 1848 to the Present, red. M. Bucur, N. Wingfield, West Lafayette 2001, s. 236-254.

Czekalski Tadeusz, Uktad Toptani-Pašić i jego następstwa. Relacje albańsko-serbskie w pierwszym roku Wielkiej Wojny, w: I wojna światowa na Bałkanach. Działania militarne i polityczne w latach 19141918, red. A. Krzak, Szczecin, 2014, s. 37-51.

Czerwiński Maciej, Chorwacki bóg Mars i serbska Golgota, „Herito”, 2014, R. 3, nr 16, s. 58-67.

Drapac Vesna, Constructing Yugoslavia. A transnational history, London, 2010.

Drapac Vesna, The Memory of War and the History of the First Yugoslavia, "War \& Society", 2005, t. 23, s. 23-41.

Meštrović Ivan, Uspomene na političke ljude i događaje, Zagreb, 1993.

Milojković-Djurić Jelena, Great War legacies in Serbian Culture, „Balcanica”, 2015, R. 66, s. 241-254.

Mitrović Andrej, Serbia's Great War, 1914-1918, West Lafayette, 2007.

Nielsen Christian Axboe, Making Yugoslavs: Identity in King Aleksandar's Yugoslavia, Toronto, 2014.

Nielsen Christian Axboe, One State, One Nation, One King: The Dictatorship of King Aleksandar and his Yugoslav Project 1929-1935, Columbia University, 2002 [nieopublikowana praca doktorska].

Radovanović Milan, British Medical Missions in Serbia 1914-1915, "London Philatelist", 2012, R. 121, nr 1396, s. 121-129.

Szczepański Wojciech, Serbski odwrót przez Albanię na przełomie 1915/1916 roku Jak doń doszło, jak zapamiętali go Serbowie?, w: I wojna światowa na Bałkanach. Działania militarne i polityczne w latach 1914-1918, red. A. Krzak, Szczecin 2014, s. 218-232.

Troch Pieter, Education and Yugoslav Nationhood in Interwar Yugoslavia. Possibilities, limitations and interactions with other national ideas, Gent 2012, [niepublikowana praca doktorska].

Troch Pieter, Nationalism and Yugoslavia. Education, Yugoslavism and the Balkans before World War II, London 2015.

Wachtel Anrew Baruch, Making a Nation, Breaking a Nation: Literature and Cultural Politics in Yugoslavia, Stanford 1998.

Walkiewicz Wiesław, Jugosławia. Państwa sukcesyjne, Warszawa 2009.

Winter Jay, Sites of Memory, Sites of Mourning. The Great War in European cultural history, Cambridge 1995.

${ }^{53}$ V. Drapac, The Memory of War and the History of the First Yugoslavia, "War \& Society", 2005, t. 23, s. 40 . 
Zieliński Bogusław, Serbska powieść historyczna. Studia nad źródłami, ideami i kierunkami rozwoju, Poznań 1998.

Глигоријевић Бранислав, Краљ Александар Карађорђевић, Београд 2010.

Грбовић Душко, Одликовања Краљевине Србије и Краљевине Срба, Хрвата и Словенаиа установљена поводом првог светског рата из збирке завичајног музеја у Јагодини, „Корени. Историјски Архив Јагодине", 2008, R. 6, s. 77-84.

Дамјановић Ратомир, Распеће Србије. Страни аутори о Србима и Србији у Великом Рату - савремении, учесници, сведоции, Београд 2014.

Карађорђевић Петар, Ратни дневник 1915-1916 (приредио и предговор написао др Драгљуб Р. Живојиновић), Београд 1984.

Манојловић-Пинтар Олга, „Благо и њима јер су славно пали за отацбину, краља и слобоу”: култ палих војника у Италији и Југославији у годинама између два светска рата, „Годишњак за друштвену историју", 2002, R. 9, nr 1-3, s. 79-98.

„Политика”, 1919-1932, nr 4182, 4786, 5263, 5474, 6347, 6372, 7430, 8088, 8822.

Радојевић Мира, Димић Љубомир, Србија у Великом Рату 1914-1918, Београд 2014.

Шаренац Данило, Топ, војник и сећање. Први светски рат и Србија 1914-2009, Београд 2014.

Живановић Милан Ж., О евакуацији српске војске из Албаније и њеној реорганизацији на Крфу (1915-1916) према франиуским документима, „Историјски часопис”, 1963-1965, R. 14-15, s. 231-307. 